\title{
Next Generation Lipophilic Bisphosphonate Shows Antitumor Effect in Colorectal Cancer In Vitro and In Vivo
}

\author{
Marcell Baranyi ${ }^{1} \cdot$ Dominika Rittler $^{1} \cdot$ Eszter Molnár $^{1} \cdot$ Senji Shirasawa ${ }^{2} \cdot$ István Jalsovszky $^{3} \cdot$ Imre Károly Varga $^{3}$. \\ Luca Hegedűs ${ }^{4}$ - Afrodíté Németh ${ }^{5}$ - Magdolna Dank ${ }^{5}$. Clemens Aigner ${ }^{4}$ • József Tóvári ${ }^{6}$ • József Tímár ${ }^{1}$. \\ Balázs Hegedüs ${ }^{1,4}$. Tamás Garay ${ }^{1,6,7,8}$
}

Received: 23 October 2019 / Accepted: 5 December 2019 / Published online: 4 January 2020

(C) Arányi Lajos Foundation 2020

\begin{abstract}
Bisphosphonates, despite proven antitumor effect in vitro in many tumor types, are currently used only for treatment of osteoporosis and bone metastasis. Colorectal cancer is the third most commonly diagnosed type of cancer and lacks targeted therapy for RAS or RAF mutation carrying cases. A new lipophilic bisphosphonate showed promising results in lung cancer models, but their effect on colorectal cancer cells was not investigated excessively. Antitumor effects and impact on RAS-related signalization of zoledronic acid (ZA) and a lipophilic bisphosphonate (BPH1222) were investigated on 7 human colorectal cancer cell lines in vitro and in vivo. Furthermore, mutant KRAS dependent effect of prenylation inhibition was investigated using isogeneic cell lines. Both bisphosphonates reduced cell viability in vitro in a dose-dependent manner. Both compounds changed cell cycle distribution similarly by increasing the proportion of cells either in the S or in the subG1 phase or both. However, BPH1222 exerted higher inhibitory effect on spheroid growth than ZA. Interestingly, we found profound alterations in phosphorylation level of Erk and S6 proteins upon ZA or BPH1222 treatment. Furthermore, investigation of a mutant KRAS isogeneic model system suggests that the drugs interfere also with the mutant KRAS proteins. In vivo experiments with KRAS mutant xenograft model also revealed growth inhibitory potential of bisphosphonate treatment. Our results show that lipophilic bisphosphonates might extend the therapeutic spectrum of bisphosphonate drugs and could be considered as additional treatment approaches in colorectal cancer.
\end{abstract}

Keywords Lipophilic bisphosphonate $\cdot$ Zoledronic acid $\cdot$ Colorectal cancer $\cdot$ In vitro $\cdot$ In vivo

Balázs Hegedűs

balazs.hegedues@rlk.uk-essen.de

Marcell Baranyi

baranyi2marci@gmail.com

Dominika Rittler

rittler.dominika@med.semmelweis-univ.hu

Eszter Molnár

molnar.eszter@med.semmelweis-univ.hu

Senji Shirasawa

sshirasa@fukuoka-u.ac.jp

István Jalsovszky

jalso@ caesar.elte.hu

Imre Károly Varga

vukracs@caesar.elte.hu

\author{
Luca Hegedüs \\ luca.hegedues@rlk.uk-essen.de \\ Afrodíté Németh \\ afrodite.nemeth@gmail.com \\ Magdolna Dank \\ dank.magdolna@med.semmelweis-univ.hu \\ Clemens Aigner \\ clemens.aigner@ruhrlandklinik.uk-essen.de \\ József Tóvári \\ jtovari@yahoo.com \\ József Tímár \\ jtimar@gmail.com \\ Tamás Garay \\ garayt@gmail.com
}

Extended author information available on the last page of the article 


\section{Background}

Colorectal cancer is the third most commonly diagnosed type of cancer and the fourth most common cause of cancer-related death worldwide [1]. Around $35-45 \%$ of the cases harbor activating KRAS, 5-7.5\% NRAS and 5-7\% BRAF mutations [2-8]. Targeted therapeutic approaches in colorectal cancer patients are limited as RAS or BRAF mutations are contraindicative for anti-EGFR antibody treatment $[6,9]$. Similarly, BRAF targeting therapies remain ineffective despite efforts to overcome primary resistance [10-12]. As direct inhibition of the currently targetable elements of RAS/RAF/ MEK/ERK signaling network shows limited effect, interfering with the posttranslational modification of RAS proteins may be a promising approach.

Nitrogenous bisphosphonates inhibit isoprenoid synthesis and thus cause impaired protein prenylation [13] - an important posttranslational modification required for the activity of several proteins involved in cell cycle regulation and cancer progression (e.g. Rho, Rac, Ras) [14]. One of the best known amino-bisphosphonates is zoledronic acid (ZA) that inhibited proliferation, induced S-phase arrest and decreased the amount of cells in G0/G1 and G2/M-phase in melanoma cells in vitro $[15,16]$. Similarly, antiproliferative effect and S-phase arrest induction were observed in breast cancer cells [17-20], non-small cell lung cancer [21, 22], pancreatic cancer [23], oral carcinoma cells [24] and even in human dermal microvascular endothelial cells [25]. Importantly, in colorectal cancer cells ZA inhibited proliferation and colony formation and increased apoptosis in vitro [26, 27]. In earlier experiments, p53-independent apoptosis induction was observed after ZA treatment in these cells [28]. Furthermore, ZA in combination with the EGFR inhibitor cetuximab decreased proliferation of colorectal cancer cells along with prenylation inhibition of RAS. It also increased apoptosis (subG1phase cells) and diminished activation of downstream effectors e.g. Erk1/2 and AKT in vitro and inhibited tumor growth in vivo [29]. In addition to results of preclinical experiments, clinical observations showed that long-term treatment with bisphosphonates reduces the risk of colorectal cancer [30-33].

Despite promising data in preclinical models, effects of ZA on primary tumors were contradictory in clinical trials [34-36]. Consequently, ZA is currently used in clinics solely for treatment of osteoporosis and bone metastases [37]. The limited therapeutic application of ZA is due to its high affinity to mineral substance of bones, and effective renal clearance resulting in its rapid disappearance from plasma [38]. Recently, lipophilic amino-bisphosphonates (e.g. BPH1222), a new subset of bisphosphonates with a lipophilic side-chain, were developed that showed antitumor activity against nonsmall cell lung cancer both in vitro and in vivo [39]. Furthermore, lipophilic amino-bisphosphonates do not show affinity towards bone mineral [40] that makes them more potent in non-bone related clinical applications.

Accordingly, the aim of this study was to compare the effect of hydrophilic and hydrophobic bisphosphonates, namely ZA and BPH1222, on colorectal cancer cells using both 2D and 3D cell culture models in vitro. Multicellular tumor spheroids (MTS) represent an in vitro model that mimics several aspects of in vivo tumor growth better compared to two-dimensional cell culture including heterogeneous cell-cell, cell-ECM interactions and 3D environment for diffusion of nutrients, oxygen and drugs [41]. Accordingly, we compared the inhibitory effects of ZA and BPH1222 on spheroid growth using MTS model which may predict in vivo effects of these drugs more precisely than conventional monolayer cell cultures. Finally, in vivo experiments were also performed, using subcutaneous xenograft mice model.

\section{Methods}

\section{Bisphosphonates}

Zoledronic acid (Novartis, Basel, $\mathrm{CH}$ ) dissolved in saline same as for clinical purposes - was used for the experiments. The lipophilic bisphosphonate BPH1222 was synthetized at the Department of Organic Chemistry, Eötvös Loránd University using a modified protocol based on the previously published methods $[42,43]$. The reactions are described in Supplemental Data.

\section{Cell Lines and Culture Conditions}

Antitumor effect of ZA and BPH1222 was investigated on seven human colon cancer cell lines. CACO2, SW1417, DLD1, HCT116, SW480, WIDR derives from ATCC. HCA7 cells derives from ECACC. Knockout clones of DLD1 and HCT116 (DKO-4 and HKh-2, respectively) where the mutant KRAS allele was removed via homologous recombination were established by Senji Shirasawa [44]. Mutational status of cell lines is presented in Table 1. Cell cultures were maintained in DMEM (Lonza, Switzerland; with $4500 \mathrm{mg} / \mathrm{l}$ glucose, pyruvate and L-glutamine) supplemented with $10 \%$ fetal calf serum (Lonza) and $1 \%$ penicillin-streptomycinamphotericin (Lonza) in tissue culture flasks at $37{ }^{\circ} \mathrm{C}$ in a humidified $5 \% \mathrm{CO}_{2}$ atmosphere. Before experiments, cells were grown to sub-confluency, washed with DPBS and trypsinized to reach single-cell suspension, then cell number was counted using Bürker.

\section{SRB Assay}

To assess short-term effect of zoledronic acid (ZA) and BPH1222 on cell viability, total protein amount based 
Sulforodamine B (SRB) assays were performed on all cell lines. Briefly, cells were plated on the inner 60 wells of a 96 well-plate, 2500 cells/well in case of HCT116, SW1417, DLD1, 5000 cells/well in case of WIDR, SW480 and 7000 cells/well were seeded from HCA7, CACO2. Differences in seeded cell number were due to variance in the cell growth rate. After $24 \mathrm{~h}$, medium was replaced to fresh medium supplemented with ZA or BPH1222 with different concentrations $(1,5,10,25$ and $50 \mu \mathrm{M})$. Following $72 \mathrm{~h}$ incubation, cells were fixed with $10 \%$ trichloroacetic acid, and stained with SRB dye for $15 \mathrm{~min}$. Plates were repeatedly washed with $1 \%$ acetic acid. Protein-bound dye was dissolved in $10 \mathrm{mM}$ Tris buffer $(\mathrm{pH}=7.4)$ and then OD was measured at $570 \mathrm{~nm}$ using a microplate reader (EL800, BioTec Instruments, Winooski, VT). Data is shown as average of three independent experiments. Effect of treatment is shown as relative to control.

\section{Clonogenic Assay}

Long-term effect of ZA and BPH1222 on cell divisions and clonogenic potential was determined using clonogenic assay. Briefly, cells were plated to 6 -well plates in 1000 cells/well density, and upon attachment treated with 1 and $2 \mu \mathrm{M} \mathrm{ZA}$ or BPH1222 for 8 days. Fresh medium was added on every 3rd day. On the 8th day, cells were fixed with mixture of methanol and acetic acid (3:1 ratio) and stained with crystal violet. Crystals were dissolved in $2 \%$ SDS solution and measured with microplate reader at $570 \mathrm{~nm}$.

\section{Cell Cycle Analysis}

Determination of DNA content in each cell was used to evaluate the number of cells in each cell cycle phase as described earlier [47]. Briefly, cells were treated with $5 \mu \mathrm{M}$ or $10 \mu \mathrm{M}$ ZA or BPH1222 for $72 \mathrm{~h}$ in 6 -well plates. Cells were trypsinized and lysed before staining with DAPI for $5 \mathrm{~min}$ at $37^{\circ} \mathrm{C}$. After adding the stabilization buffer $10 \mu \mathrm{l}$ of each sample was loaded onto an 8-well NC slide. NucleoCounter NC$3000^{\mathrm{TM}}$ system (Chemometec) was used to quantify cellular fluorescence.

\section{Western Blot Analyses}

KRAS related cell signaling was investigated by Western blot analyses. Following $48 \mathrm{~h}$ treatment with $10 \mu \mathrm{M}$ ZA or BPH1222 in 6-well plates, cells were washed with PBS and fixed with $6 \%$ trichloroacetic acid at $4{ }^{\circ} \mathrm{C}$ for an hour. Then cells were mechanically harvested using cell scrapers and precipitated protein was dissolved in modified Läemmli-type sample buffer containing $0.02 \%$ bromophenol blue, $10 \%$ glycerol, 2\% SDS, $100 \mathrm{mM}$ dithiothreitol (DTT), $5 \mathrm{mM}$ EDTA, $125 \mathrm{mg} / \mathrm{ml}$ urea, $90 \mathrm{mM}$ Tris-HCl, $\mathrm{pH}$ 7.9. Protein concentration was determined by using Qubit Fluorometer. Equal amounts of protein were separated on $10 \%$ poliacrylamid gels and transferred to PVDF membranes. Analyses of Ras-related signaling were performed using pErk (9101S, Cell Signaling), Erk (9102S, Cell Signaling), pS6 (2215S, Cell Signaling), S6 (2217S, Cell Signaling) primary antibodies. For detection of apoptosis PARP (9545S, Cell Signaling) primary antibody was used. All primary antibodies were dissolved according to the manufacturer's instructions in 5\% BSA or dry milk in 1x TBST buffer in 1:1000 ratio. Membranes were blocked in 5\% dry milk in $1 \mathrm{x}$ TBST for an hour in room temperature (RT), then incubated with primary antibodies for overnight at $4{ }^{\circ} \mathrm{C}$. HSP conjugated rabbit secondary antibodies $(1: 10000,1 \mathrm{~h}, \mathrm{RT})$ and Pierce ECL Western Blotting Substrate (Thermo Scientific) were used to visualize protein bands. Bands were normalized to total protein determined by Ponceau staining. Quantification was performed using ImageJ software. Each cell line was analyzed in 3 biological replicates.

Table 1 Mutational status of the used cell lines

\begin{tabular}{|c|c|c|c|c|c|c|c|}
\hline & $\mathrm{CACO}_{2}{ }^{1}$ & $\mathrm{HCA}^{3}$ & WIDR $^{4}$ & SW1417 & $\mathrm{DLD}^{4}{ }^{4}$ & HCT116 $6^{1,2}$ & SW480 ${ }^{1}$ \\
\hline ERBB receptors & $\mathrm{ERBB}^{\mathrm{b}}$ & $\mathrm{ERBB}^{\mathrm{b}}{ }^{\mathrm{b}}$ & WT & WT & $\mathrm{ERBB}^{\mathrm{b}}$ & $\mathrm{ERBB}^{\mathrm{a}}{ }^{\mathrm{a}}$ & ERBB2 $^{\mathrm{a}}$ \\
\hline MAPK mutation & WT & WT & WT & $\mathrm{MAP} 2 \mathrm{~K} 4^{\mathrm{b}}$ & $\begin{array}{l}\text { Mutations of } 7 \text { different } \\
\text { MAPK, MAP2K, } \\
\text { MAP3K genes }\end{array}$ & $\begin{array}{l}\text { Mutations of } 12 \text { different } \\
\text { MAPK, MAP2K, } \\
\text { MAP3K genes }\end{array}$ & WT \\
\hline KRAS & WT & WT & WT & WT & p.G13D & p.G13D & p.G12 V \\
\hline BRAF & WT & WT & p.V600E & p.V600E & WT & WT & WT \\
\hline PTEN & WT & WT & WT & WT & WT & WT & WT \\
\hline PI3K/AKT pathway & PIK $3 C 2 B^{b}$ & $\begin{array}{l}\text { PIK3C } 3^{\mathrm{b}} \text { PIK3R } 2^{\mathrm{b}} \\
\text { PIK3R } 4^{\mathrm{b}}\end{array}$ & $\mathrm{PIK} \mathrm{CA}^{\mathrm{b}}$ & $\mathrm{PDK} 1^{\mathrm{b}}$ & $\begin{array}{l}\text { PI3KCA }{ }^{\mathrm{b}} ; \mathrm{PI}^{3} \mathrm{KCB}^{\mathrm{b}} ; \\
\text { PI3KC2B }^{\mathrm{b}} \mathrm{PI} 3 \mathrm{KR} 1^{\mathrm{b}} ; \\
\text { RICTOR }^{\mathrm{b}}\end{array}$ & $\begin{array}{l}\text { PI3KCA }{ }^{\mathrm{b}} ; \mathrm{PI} 3 \mathrm{KCD}^{\mathrm{c}} ; \\
\text { PI3KR1 }^{\mathrm{c}} ; \mathrm{PI} 3 \mathrm{KR} 4^{\mathrm{b}}\end{array}$ & - \\
\hline
\end{tabular}

Mutational types: ${ }^{a}$ nonsense; ${ }^{b}$ missense; ${ }^{c}$ deletion. Data is obtained from: 1) CCLE database; 2) COSMIC database; 3) [45]; 4) [46] 


\section{Investigation of Mutant KRAS Allele Dependent Effects of Prenylation Inhibition}

In order to investigate whether prenylation inhibition exerts its effects on mutant KRAS, we used knockout derivatives of DLD1 and HCT116 that both harbor heterozygous G13D mutation on KRAS. Mutant KRAS allele were deleted via homologous recombination as described earlier [44]. DKO-4 was generated from DLD1, while HKh-2 was generated from HCT116. To reveal differences between parental lines and their derivatives, short-term SRB assay and long-term clonogenic assay were performed as described above. Changes in cell signaling were also investigated by Western blot analyses.

\section{Spheroid Generation and Treatment}

Spheroids were generated via hanging drop method. $6 \mu 1$ drops were placed into rings of the lid of a 96-well-plate and then was reversed and placed back to the plate. Each drop contained approximately 300 cells in case of DLD1 and HCT116 and 700 cells for WIDR and SW1417. Cell densities were critical in each cell line for stable sphere formation and determined in primary experiments. To avoid evaporation of drops, $70 \mu \mathrm{l}$ DPBS were put into each well. Individual spheroids were formed during 72 or $96 \mathrm{~h}$ of incubation in the hanging drops and then we transferred each to separate wells of the 96-well Ultra Low Attachment Plates (Corning). Following the transfer of the spheroids, they were exposed to treatment with 2 and $5 \mu \mathrm{M} \mathrm{ZA}$ and BPH1222 for 12 days. Pictures were taken of each spheroid on the first day, and then every 3rd day during treatment. Medium was partially changed on every 3rd day: briefly, $90 \mu \mathrm{l}$ medium was taken out carefully and $100 \mu \mathrm{l}$ of fresh medium (to compensate evaporation) was added followed by gentle suspending to remove dead cells from spheroids. Pictures were analyzed and spheroid volume calculated using ImageJ free software as already described [48]. Data is shown as average of at least ten spheroids from three independent experiments.

\section{Subcutaneous Xenograft Model}

HCT116 and SW1417 human colorectal cancer cells $\left(3 \times 10^{6}\right.$ and $5 \times 10^{6}$ in $0.2 \mathrm{ml}$, respectively) were subcutaneously injected in male SCID mice, at a weight of 30-33 g. Tumors were measurable 6 days after injection. At this point, animals were randomized and grouped according to treatment conditions (control, ZA and BPH1222 treated). Each group contained 10 mice. Animals were treated intraperitoneally twice a week for 3 weeks with $1.47 \mathrm{~mol} / \mathrm{kg} \mathrm{ZA}$ or BPH1222. Controls received $100 \mu \mathrm{l}$ of $0.9 \% \mathrm{NaCl}$ solution. The subcutaneous tumors were measured with a caliper and tumor-volumes were calculated with the formula for the volume of a prolate ellipsoid $\left(4 / 3 \pi \times\left(\right.\right.$ length $\times$ width $\left.\left.^{2}\right)\right)$ and expressed in $\mathrm{mm}^{3}$. In case of HCT116 three animals per group were sacrificed after 14 days of treatment to obtain tumor samples for histological evaluation. After the last measurement on day 21, the remaining animals ( 7 in each group) were sacrificed by cervical dislocation.

SW1417 xenografts showed high growth rate and had to be terminated after 15 days.

Animals were provided by the Department of Experimental Pharmacology, National Institute of Oncology, H-1122, Budapest, Hungary and all experiments were carried out in accordance with the Guidelines for Animal Experiments and were approved for the Department of Experimental Pharmacology in the National Institute of Oncology, Budapest, Hungary (permission number: PEI/ 001/2574-6/2015).

\section{Statistics}

Normal distribution of dependent variables was confirmed using Kolmogorov-Smirnov normality test. To determine statistical differences between groups, repeated measures ANOVA was performed for spheroid data and in vivo experiments. Two-way ANOVA was performed for SRB assay data. All ANOVA tests were followed by Bonferroni's post hoc test. Clonogenic assays of DLD1 and HCT116 with their knockout counterparts were compared by Mann-Whitney U test. Otherwise, in clonogenic assays non-parametric KruskalWallis and post hoc Dunn's multiple comparison test was used. Statistical significance was established at $p<0.05$. All statistical analyses were computed by GraphPad Prism 5 (GraphPad Software Inc., USA, San Diego, CA).

\section{Results}

\section{Short-Term Effect of ZA and BPH1222 on Cell Viability}

To assess dose dependent cytotoxic effect of ZA and BPH1222 on colorectal cancer cells with different mutational status, short-term SRB assay was performed on seven human colon cancer lines (Fig. 1). 72-h-treatment with either ZA or BPH1222 decreased cell viability in all examined cell lines in a dose dependent manner. However, there was a considerable variation in sensitivity to bisphosphonates among the cell lines harboring same oncogenic mutation. Among the KRAS mutant cell lines HCT116 cells were much more sensitive to both treatments than SW480 and DLD-1 cells, and the viability of double wild-type $\mathrm{CACO} 2$ cells decreased at a lower concentration after bisphosphonates treatment than the other double wild-type HCA7 cells. We found significant differences in the antitumor effect of ZA and BPH1222 treatments in the following cell lines. ZA treatment showed significantly higher 
efficacy in HCA7 cells at 5 and $10 \mu \mathrm{M}$ concentrations than BPH1222. In contrast, significantly higher sensitivity towards BPH1222 treatment was found in SW480 and WIDR cells at 10,25 and $50 \mu \mathrm{M}$.

\section{Effects of Long-Term Exposure to ZA and BPH1222}

Clonogenic assay was used to investigate the long-term effects of treatments with ZA or BPH1222 on long-term growth and clonogenic potential of colorectal cancer cells (Fig. 2). Similarly, there was no significant difference in sensitivity to bisphosphonates according to the oncogenic mutations. ZA inhibited clonogenic cell growth significantly more effective in HCA7 cells both at $1 \mu \mathrm{M}$ and $2 \mu \mathrm{M}$ concentrations, whereas BPH1222 was much more effective in SW480 at $1 \mu \mathrm{M}$ concentration. Biologically relevant - albeit statistically not significant - differences were observed in HCT116 cell line where BPH1222 inhibited clonogenic growth at a higher extent than ZA.

\section{Effects of ZA and BPH1222 Treatments on the Cell Cycle of Colorectal Cancer Cells}

DAPI staining and image cytometry were used to determine the effects of treatment with ZA or BPH1222 on colorectal cancer cells (Fig. 3). In CACO2 and WIDR cells, both bisphosphonates increased proportion of cells in S-phase and subG1-phase while the ratio of the cells in the G0/G1 phase strongly decreased. This effect was more pronounced after BPH1222 treatment. Namely, increase in S-phase was statistically significant in WIDR cells following both concentration of BPH1222 and after the $10 \mu \mathrm{M}$ concentration treatment in $\mathrm{CACO} 2$ cells. Similarly, significant increase of subG1-phase was observed in $\mathrm{CACO} 2$ cells after the higher concentration BPH1222 treatment. In KRAS mutant HCT116 cells both treatments had only a minimal effect on cell cycle, however, a slight increase in the ratio of tumor cells in subG1 phase was detected after BPH1222 treatment.

\section{Effects of ZA and BPH1222 on Cell Signaling and Apoptosis Induction}

Exposure to ZA and BPH1222 had distinct effects on the $\mathrm{PI} 3 \mathrm{~K} / \mathrm{AKT}$ and RAF/MEK/ERK pathways, the two major signaling axes downstream from KRAS (Fig. 4). Interestingly, p-Erk was elevated in the three KRAS-mutant cells and BRAF-mutant SW1417, while showed no change or a slight decrease in the other BRAF-mutant and also in double wild-type cell lines. In contrast, level of p-S6 were robustly decreased in all cell lines except for BRAF mutant SW1417, where we found a modest increase in S6 activation. Of note, in most of the cases the effects (both increase or decrease of the given phosphoprotein) were more pronounced upon treatment with BPH1222. In addition, level of cleaved PARP revealed apoptosis induction upon prenylation-inhibition in HCT116, CACO2 and HCA7 cell lines.

\section{Investigation of Mutant KRAS Allele Dependent Effects of Prenylation Inhibition}

To reveal whether prenylation inhibitor drugs exert their effect through blocking oncogenic KRAS protein, we performed SRB and clonogenic assay on KRAS-mutant DLD1 (G13D/WT) and HCT116 (G13D/WT) cell lines and their knockout derivatives DKO-4 (-/WT), HKh-2 (-/WT) (Fig. 5a, b). We found increased sensitivity to prenylation inhibition in DKO-4 cells compared to DLD1 cells especially in clonogenic assays. In contrast, reduced prenylation inhibition sensitivity was observed in case of HKh-2 cells when compared to HCT116 upon both short- and long-term treatments. Differences between clones and parental lines in response to BPH treatment were found to be statistically significant.

Cell signaling also showed changes between parental lines and their knockout derivatives (Fig. 5c). Overall, drug induced elevated p-Erk level observed in DLD1 and HCT116 decreased in all knockout clones, with HKh-2 showing high similarity to wild-type cell lines CACO2 and HCA7. a

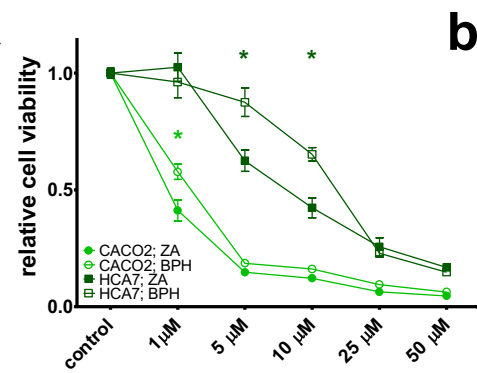

b

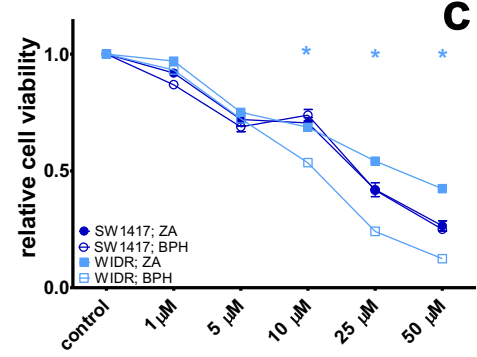

C

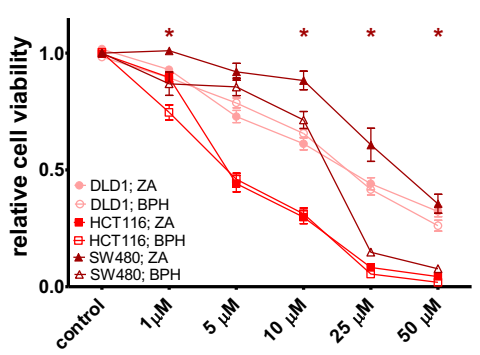

Fig. 1 Results of short-term $(72 \mathrm{~h})$ treatment with ZA or BPH1222 on human colon cancer cell lines. a Double wild-type CACO2 and HCA7, b BRAF-mutant WIDR, SW1417 c) KRAS-mutant DLD1, HCT116, SW480 cells. Both compounds inhibited cell viability in a dose- dependent manner. Data is shown as average \pm SEM of three independent experiments for each cell line. Asterisk indicates significant difference with $p<0.05$ between ZA and BPH1222 with two-way ANOVA and Bonferroni post hoc test 


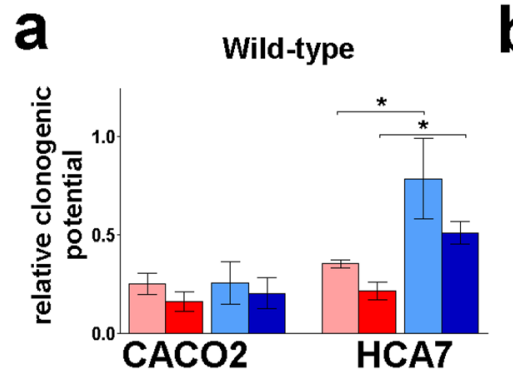

\section{$1 \mu \mathrm{M} Z \mathrm{ZA} \quad \square 2 \mu \mathrm{M} Z \mathrm{AA}$}

Fig. 2 Effect of 8-day-long treatment on clonogenic potential of colorectal cancer cells. a Double wild-type CACO2 and HCA7, b BRAF-mutant SW1417, WIDR, c KRAS-mutant DLD1, HCT116, SW480 cells. Both compounds inhibited colony formation in a dosedependent manner independently from mutational status. Data is shown

Furthermore, the level of cleaved PARP strongly decreased in HKh-2 cells compared to HCT116. This result suggests that loss of the mutant KRAS allele reduces the apoptosisinducing ability of prenylation inhibition.

\section{Effects of ZA and BPH1222 Treatment in 3D Spheroid Cell Culture}

Growth curves of spheroids treated with ZA and BPH1222 are shown in Fig. 6. Two KRAS-mutant (DLD1 and HCT116)
BRAF-mutant

C

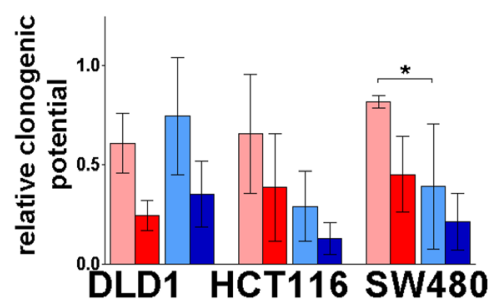

\section{$1 \mu \mathrm{M} \mathrm{BPH} \quad 2 \mu \mathrm{M} \mathrm{BPH}$}

as average \pm SEM of three independent experiments for each cell line. Asterisk indicates significant difference with $p<0.05$ between ZA and BPH1222 with non-parametric Kruskal-Wallis followed by post hoc Dunn's multiple comparison test

and two BRAF-mutant (SW1417 and WIDR) cell lines from the seven examined colorectal cancer cell lines were capable of spheroid formation. Interestingly, lipophilic BPH1222 inhibited spheroid growth more efficiently than ZA. The $2 \mu \mathrm{M}$ dose treatment of BPH1222 was significantly more effective as the $2 \mu \mathrm{M}$ dose ZA treatment in all four cell lines. In case of the $5 \mu \mathrm{M}$ treatment this difference was only seen in DLD1 and SW1417 cells. Importantly, the observed effects were independent of KRAS/BRAF mutational status. Of note, BPH1222 showed higher antitumor activity in DLD1 cells

a

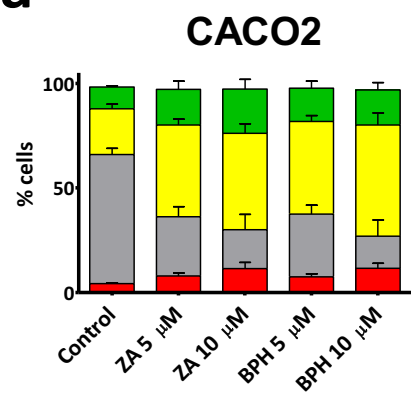

WIDR

HCT116

\section{b}

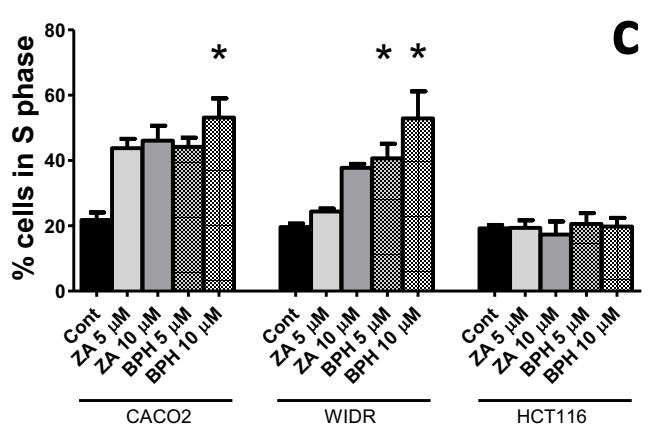

Fig. 3 Distribution of cells among cell cycle phases in colorectal cancer cells after 72-h-long bisphosphonate treatment. a-c Cell cycle distribution after bisphosphonate treatment in CACO2, WIDR and HCT116 cells. Percentage of cells in S-phase (d) and subG1-phase (e) after bisphosphonate treatments. Both compounds increased the proportion of cells in S- and subG1-phase in wild-type and BRA-
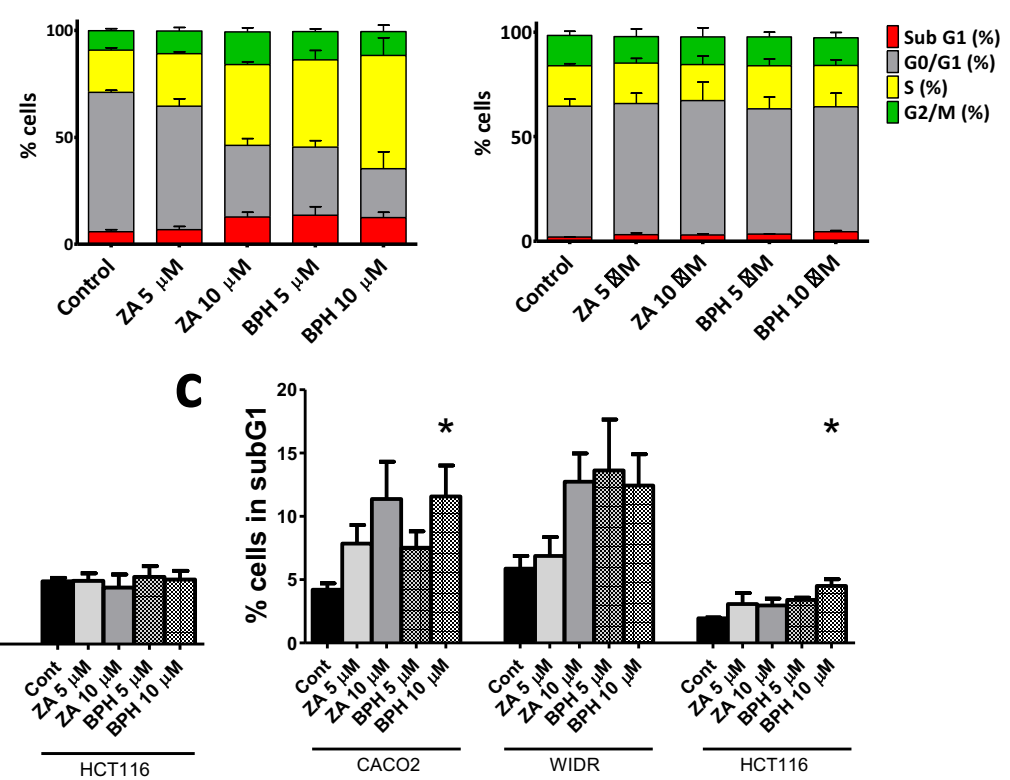

mutant cells but no such changes were observed in KRAS-mutant cells. Data is shown as average \pm SEM of three independent experiments for each cell line. Asterisk indicates significant difference with $p<0.05$ between control and treatment with non-parametric Kruskal-Wallis followed by post hoc Dunn's multiple comparison test 
even though these cells were significantly more sensitive to $\mathrm{ZA}$ in the $2 \mathrm{D}$ experiments.

\section{Effects of ZA and BPH1222 Treatment In Vivo}

To assess the effect of ZA and BPH1222 on primary tumor growth, we injected HCT116 KRAS-mutant and SW1417 BRAF-mutant human colorectal cancer cells subcutaneously into the flank of male SCID mice. Both bisphosphonate compounds decreased the subcutaneous growth of HCT116 cells (Fig. 7a). Interestingly, BPH1222 treatment showed greater antitumor effect than ZA from the 7th day of treatment. Importantly, BPH1222 treatment resulted in significant decrease in tumor volume compared to control.

Despite promising results on KRAS-mutant HCT116 cells, the BRAF-mutant SW1417 cells exhibited a resistant phenotype to both bisphosphonate treatments in vivo as both treatments failed to slow down tumor growth (Fig. 7b).

\section{Discussion}

The aim of present study was to compare the anticancer effects of the conventional bisphosphonate ZA, currently used for treatment of osteoporosis and bone metastases, and its lipophilic derivative, BPH1222 on colorectal cancer cells. Effects on prenylation inhibition on the mutant KRAS protein were also investigated.

In earlier preclinical studies ZA, showed the highest antitumor efficacy against breast cancer cells compared to other bisphosphonates such as pamidronate, clodronate and EB 1053 [20]. Similarly, antiproliferative and apoptotic effects of ZA were shown in pancreatic cancer cells in vitro [23]. Of note, previously ZA inhibited proliferation and induced apoptosis in vitro and decreased tumor growth in vivo in experimental models of colorectal cancer [26, 27].

However, high affinity to bone mineral of conventional bisphosphonates, including ZA, limits their usability in vivo for non-bone related applications [38]. In order to overcome

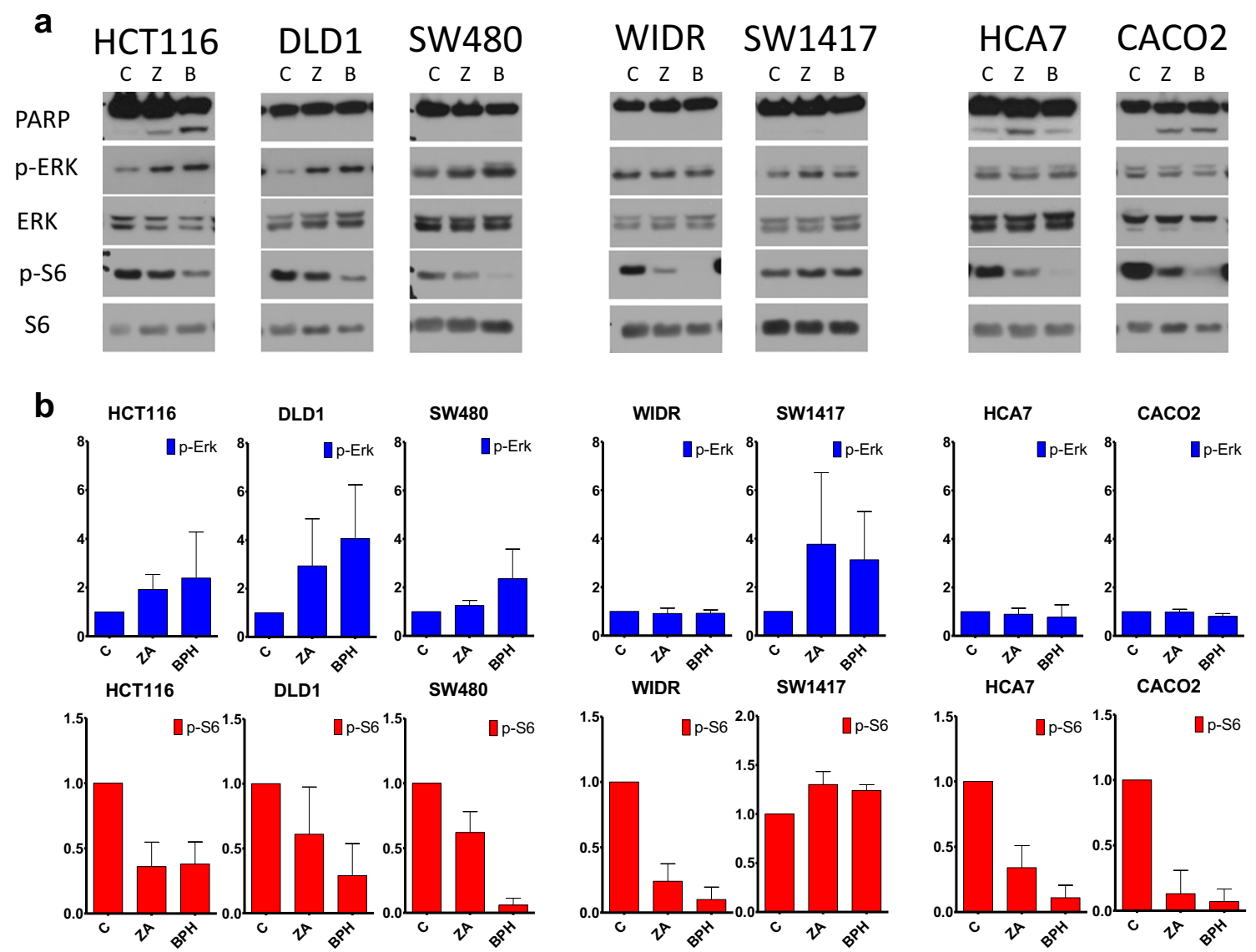

Fig. 4 KRAS related cell signaling analyses in colorectal cells upon $48 \mathrm{~h}$ treatment with $10 \mu \mathrm{M} \mathrm{ZA}$ or BPH1222. a representative images of the investigated proteins, b changes in level of p-Erk and p-S6 upon treatment normalized to control. Ponceau staining of total protein was used for normalization. Apoptosis induction was detected in HCT116, HCA7 and CACO2 cells marked by appearance of cleaved PARP. In
HCT116 cells BPH1222 had a stronger apoptotic effect as ZA, while in HCA7 cells ZA induced more apoptosis. Level of p-S6 decreased profoundly in all cell lines after treatment, except for SW1417 where even a modest increase was observed. Expression level of p-Erk did not change or is increased upon treatment in all cell lines. Data is shown as average $\pm \mathrm{SD}$ of three independent experiments for each cell line 

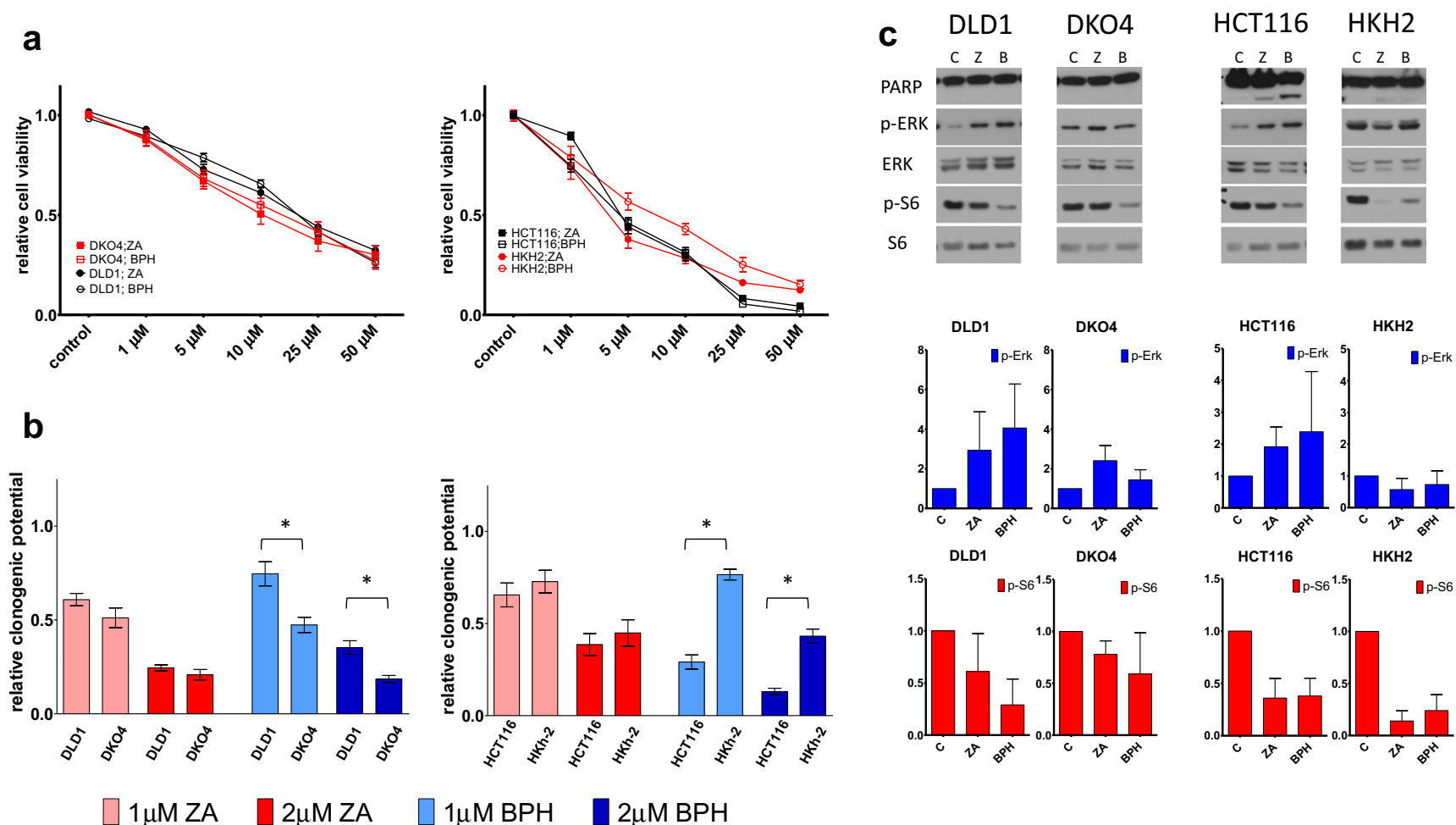

Fig. 5 The impact of the deletion of the KRAS-mutant allele. DLD1 and HCT116 are KRAS mutant cell lines (G13D/WT). Mutant KRAS allele was deleted from DKO-4, HKh-2 (-/WT) cells. DKO-4 is a derivative of DLD1, while HKh-2 derives from HCT116 cell line. a short-term b longterm treatment differences between parental lines and knockout derivatives. The clonogenic potential of DKO-4 was stronger inhibited by both ZA and BPH1222 compared to DLD1, while knockout clone of

HCT116 (HKh-2) became more resistant to prenylation inhibition upon long-term treatment. Statistical significance was calculated with nonparametric Mann-Whitney U test. c Cell signaling analyses revealed that expression level of p-Erk did not increase after drug treatment in the knockout clones but only in the parental cell lines. Furthermore, drug-induced apoptosis also showed significant reduction in HKh-2 cells compared to HCT116

a

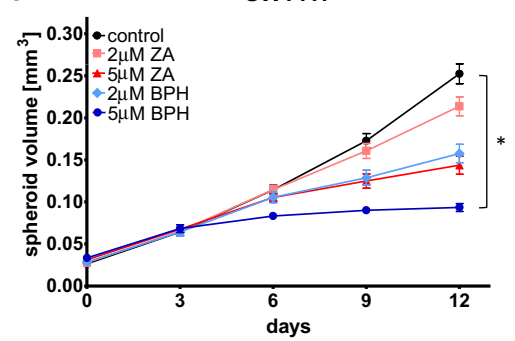

C

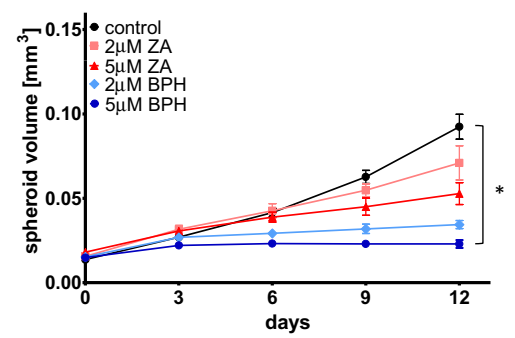

b

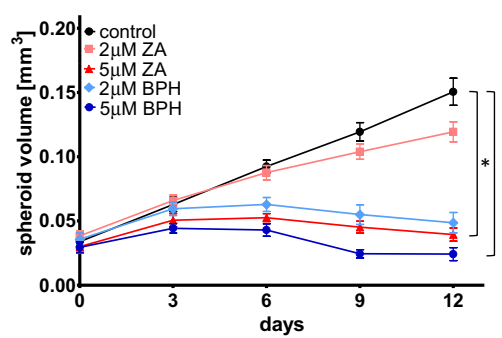

d

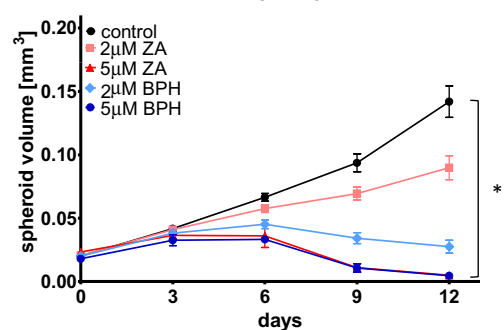

e

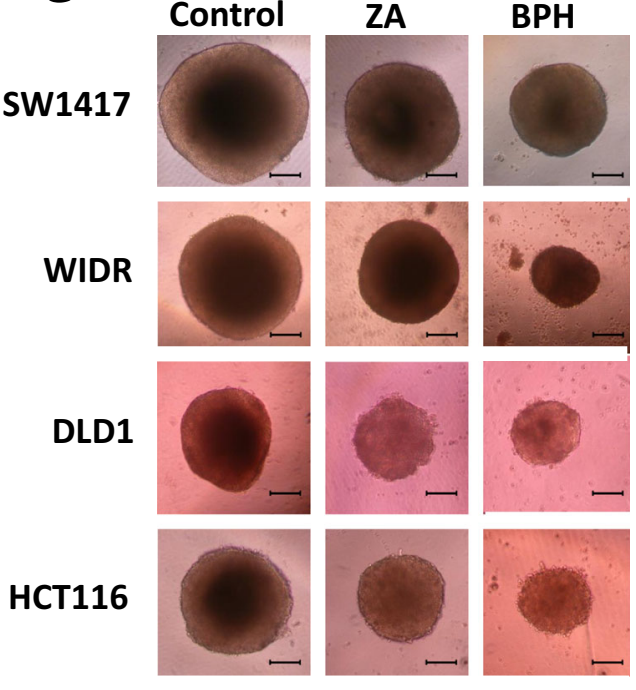

Fig. 6 Growth curves of spheroids during 12-day-long treatment with ZA or BPH1222. a-d Spheroid volume was calculated based on pictures taken every third day during treatment (see details in Methods section). e Representative pictures of spheroids at day 12 and $2 \mu \mathrm{M}$ treatment. Scale bar $=200 \mu \mathrm{m}$. BPH1222 inhibited spheroid growth more efficiently in each cell line. Data is shown as average $\pm \mathrm{SEM}$ of at least ten spheroids from three independent experiments for each cell line. Black asterisk indicate significant difference with $p<0.05$ compared to control. Statistical significance was calculated with repeated measures ANOVA and Bonferroni post hoc tests 
Fig. 7 In vivo xenograft models of colorectal cancer cells. a KRAS-mutant HCT116 and b BRAF-mutant SW1417

subcutaneous tumor growth after $1.47 \mathrm{~mol} / \mathrm{kg}$ (equimolar) $\mathrm{ZA}$ and BPH1222 treatment. Data shown as average \pm SEM; Asterisk indicates significant difference to control with $p<0.05$ calculated with repeated measures ANOVA and Bonferroni post hoc tests a

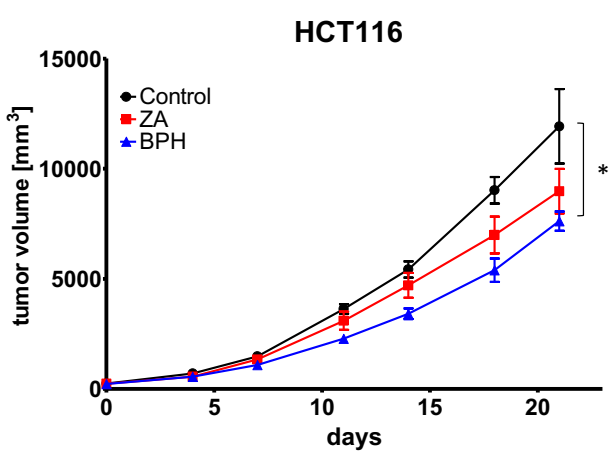

b

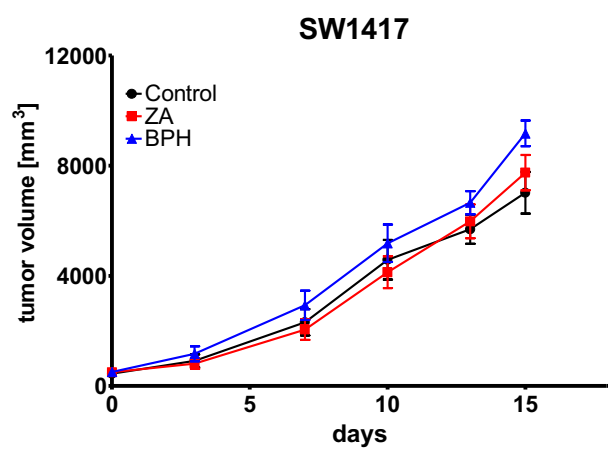

this hurdle, lipophilic bisphosphonates have been recently developed [40]. These drugs were found to be effective in preclinical models of lung cancer not only in vitro but also in vivo as hydrophobicity prevents their bone accumulation, resulting in longer plasma half-life [39].

Using two-dimensional cell cultures, we found that both ZA and BPH1222 exert dose-dependent inhibitory effect measured with short- and long-term viability assay on colorectal cancer cells. Furthermore, upon both short- and long-term exposure to drugs, notable differences were observed between sensitivity of cell lines to ZA and BPH1222. Importantly, differences in cell viability did not correlate with any major mutational alterations of cells, and no drug was found to be exclusively superior to the other in any mutational groups.

As previously described, $100 \mu \mathrm{M}$ ZA doubled the amount of apoptotic cells after 12-h treatment in melanoma cells [15]. Similarly, five-fold increase of cells in subG1 phase was detected after $72 \mathrm{~h}$ treatment with $25 \mu \mathrm{M}$ ZA in breast cancer cells [24]. In line with this, twofold increase in apoptotic cell number, parallel with an S-phase arrest were measured after 24-h treatment with $100 \mu \mathrm{M}$ ZA using T47D and BT20 human breast cancer cell lines [19]. Of note, in HCT116 colorectal cancer cells $25 \mu \mathrm{M} Z \mathrm{ZA}$ increased apoptosis measured by the amount of cleaved PARP [27] and using flow cytometry [26]. Similarly, apoptosis induction was observed by the evaluation of TUNEL positive cells in mice xenograft models of colorectal cancer cells upon the treatment with ZA [29].

The used $10 \mu \mathrm{M} Z \mathrm{ZA}$ concentration is smaller than used in the literature and still a modest but consequent increase in subG1- and/or S-phase was observed. Of note, the impact of BPH1222 on subG1-phase increase and S-phase arrest was more profound as compared to $\mathrm{ZA}$, although did not reach statistical significance.

Our previous study on human lung adenocarcinoma cell lines indicated that EGFR- and KRAS double wild-type cells are the most sensitive toward ZA [49]. On the other hand, BRAF-mutant and PTEN wild-type melanoma cells were less sensitive to ZA as compared to NRAS-mutant or BRAFmutant and PTEN null cells in which remarkable proliferation inhibition and apoptosis induction was observed after ZA treatment in vitro [16].

With regard to other molecular alterations affecting RTK pathway, both the wild-type and the mutant HER expressing, but not HER-low tumor cells, showed sensitivity towards ZA treatment in breast and lung cancer models [21]. Furthermore, BPH1222 in combination with rapamycin showed synergistic effect on KRAS-mutant lung cancer models [39].

These results show that prenylation inhibition affects RTK signaling in a diverse and currently not fully understood way. Consequently, we investigated effects of ZA and BPH1222 on Ras-related signaling pathways. Interestingly, we found that prenylation inhibition had profound effect on the level of $p$ Erk and p-S6 which are elements of the two major signaling pathways downstream of Ras; namely RAF/MEK/ERK and PI3K/AKT.

In all cell lines, except for SW1417, p-S6 level was strongly decreased upon prenylation inhibition. S6, a key component of the PI3K/mTOR axis, is also considered as an important element of various signaling pathways critical for cell survival and growth. Thus, reduced phosphorylation of S6 was shown to be a highly sensitive marker of drug response [50]. This observation is in line with our in vivo experiments: we found that SW1417 was resistant to treatment with ZA and BPH1222. Additionally, this was the only cell line where level of p-S6 was not decreased upon prenylation inhibition.

Interestingly, in all KRAS-mutant cell lines and also in BRAF-mutant SW1417, we observed elevated p-Erk level upon treatment with ZA or BPH1222. However, in HCA7, CACO2 and BRAF mutant WIDR, no change on p-Erk level was observed. To reveal whether these observations shows any connections with mutant KRAS protein activation, we used two isogeneic cell models for KRAS mutation. These models consists of parental cell lines harboring heterozygous KRAS G13D mutations and their knockout derivatives whereby mutant KRAS allele was removed via homologous recombination. We observed profound differences in sensitivity to ZA and BPH1222 treatment between these cell line pairs. In addition, while p-Erk level was elevated upon bisphosphonate treatment in the parental cell lines, it only showed a modest 
increase or no increase in the knockout clones similarly to KRAS wild-type $\mathrm{CACO} 2, \mathrm{HCA} 7$ and WIDR cell lines (Figs. 4 and 5C).

We found that DKO-4, the mutant KRAS-knockout derivative of DLD1, became more sensitive to prenylation inhibition. In contrast, the mutant KRAS-knockout clone of HCT116 was more resistant to both short- and long-term treatments. Furthermore, we found that prenylation-inhibition elevated cleaved PARP level significantly in HCT116 (G13D/WT; TP53 WT), but this effect was strongly decreased in its knockout derivative HKh-2 (-/WT; TP53 WT). This suggests that apoptosis induction by these drugs was dependent on the presence of the mutant KRAS allele in this cell line (Fig. 5c). However, we detected no apoptosis induction in neither DLD1 (G13D/WT; TP53 MUT) nor DKO4 (-/WT; TP53 MUT). Overall, these results suggest that prenylation inhibition interfere with mutant KRAS protein in a cell line dependent and currently not fully understood way.

Distinct polarity of ZA and BPH1222 suggested differences in behavior and efficacy in $3 \mathrm{D}$ environment. Accordingly, we compared antitumor effects of ZA and BPH1222 on multicellular tumor spheroid (MTS) cultures. This 3D model mimicks certain aspects of in vivo conditions more realistically than conventional $2 \mathrm{D}$ cell cultures, namely heterogeneous cell-cell, cell-ECM interactions and diffusion of nutrients, oxygen and drugs [41]. As hypothesized, based on its lipophilic character, BPH1222 showed significantly higher inhibitory effect on spheroid growth than ZA in all cell lines, regardless of their mutational status or the results of SRB and clonogenic assays in 2D cultures. Furthermore, BPH1222 exerted higher antitumor effect even on cell lines with higher sensitivity to ZA treatment under 2D conditions. In line with 3D in vitro results, lipophilic bisphosphonates were shown to be more effective in in vivo models of lung cancer [39]. This finding was confirmed in our study: our in vivo experiment using a subcutaneous xenograft model of KRAS-mutant HCT116 colorectal cancer cells showed that BPH1222 could inhibit tumor growth more effectively than ZA.

However, in the BRAF-mutant SW1417 cell line both bisphosphonates failed to slow down tumor growth in in vivo xenograft experiment (Fig. 7b). Although SW1417 showed sensitivity to bisphosphonate treatment in 2D and $3 \mathrm{D}$ in vitro, it was the only cell line where level of p-S6 had not decreased. Phosphorylation level of p-S6 is considered as an important marker of drug response [50]. Furthermore, SW1417 showed the highest growth rate in 3D in vitro experiments and it was the most resistant to prenylation inhibition among spheroid forming cell lines. Additionally, BRAF V600E mutant colorectal cancer has a poor prognosis, as even the mutation specific inhibitor vemurafenib failed to show clinical activity in BRAF V600E mutant cases likely due to feedback reactivation of EGFR pathway [12].

\section{Conclusion}

In summary, our data suggests that BPH1222 is a more potent anticancer compound compared to zoledronic acid in 3D model systems. Altogether, our findings prompt further investigation of the potential application of lipophilic bisphosphonates for cancer treatment including colorectal cancer.

Acknowledgements The authors thank Anita Hídvégi and Violetta Piurkó for their excellent technical assistance.

Authors' Contributions TG, JTímár, CA and BH carried out the study design, TG, MB and $\mathrm{BH}$ drafted the manuscript. TG, MB, DR, EM, AN, and LH carried out the experiments. SS established knockout clones DKO-4 and HKh-2. IJ and IKV developed the synthesis method and synthetized the compound BPH1222. TG, MB, DR and EM analyzed and interpreted the data. JTóvari contributed with the animal experiment. JTímár and MD was involved in the revision of the manuscript. All authors read and approved the submitted version.

Funding Information This work was supported by the Hungarian National Research, Development and Innovation Office (MOB80325 to BH and NVKP-16-1-2016-0020 to JTímár), Hungarian Scientific Research Fund - OTKA (K116151 to JTímár) and by the HAS Postdoctoral Fellowship Program (450,071 to TG). The funding bodies did not play a role in the design of the study, the collection, analysis and interpretation of data or in the preparation of the manuscript.

Data Availability The datasets used and/or analyzed during the current study available from the corresponding author upon reasonable request.

\section{Compliance with Ethical Standards}

Ethics Approval and Consent to Participate Animal-model experiments were conducted following the standards and procedures approved by the Animal Care and Use Committee of the National Institute of Oncology, Budapest (license number: PEI/001/2574-6/2015). Animals were the properties of Department of Experimental Pharmacology, National Institute of Oncology, H-1122, Budapest, Hungary. József Tóvári, head of Department of Experimental Pharmacology, and co-author of this study, carried out animal experiments.

Consent for Publication Not applicable.

Competing Interests The authors declare that they have no competing interests.

Abbreviations ZA, Zoledronic acid; SRBq, Sulforhodamine B; MTS, multicellular tumor spheroid.

\section{References}

1. Mcguire S (2016) World Cancer Report 2014. Geneva, Switzerland: World Health Organization, International Agency for Research on Cancer, WHO Press, 2015. Adv Nutr 7(2):418419. https://doi.org/10.3945/an.116.012211

2. Fearon ER (2011) Molecular genetics of colorectal cancer. Annu Rev Pathol 6:479-507. https://doi.org/10.1146/annurev-pathol011110-130235 
3. Lau KS, Haigis KM (2009) Non-redundancy within the RAS oncogene family: insights into mutational disparities in cancer. Mol Cells 28(4):315-320. https://doi.org/10.1007/s10059-009-0143-7

4. Wood LD, Parsons DW, Jones S, Lin J, Sjoblom T, Leary RJ, Shen D, Boca SM, Barber T, Ptak J, Silliman N, Szabo S, Dezso Z, Ustyanksky V, Nikolskaya T, Nikolsky Y, Karchin R, Wilson PA, Kaminker JS, Zhang Z, Croshaw R, Willis J, Dawson D, Shipitsin M, Willson JK, Sukumar S, Polyak K, Park BH, Pethiyagoda CL, Pant PV, Ballinger DG, Sparks AB, Hartigan J, Smith DR, Suh E, Papadopoulos N, Buckhaults P, Markowitz SD, Parmigiani G, Kinzler KW, Velculescu VE, Vogelstein B (2007) The genomic landscapes of human breast and colorectal cancers. Science 318(5853):1108-1113. https://doi.org/10.1126/science.1145720

5. Baldus SE, Schaefer KL, Engers R, Hartleb D, Stoecklein NH, Gabbert HE (2010) Prevalence and heterogeneity of KRAS, BRAF, and PIK3CA mutations in primary colorectal adenocarcinomas and their corresponding metastases. Clin Cancer Res 16(3):790-799. https://doi.org/10.1158/1078-0432.CCR-092446

6. De Roock W, Claes B, Bernasconi D, De Schutter J, Biesmans B, Fountzilas G, Kalogeras KT, Kotoula V, Papamichael D, LaurentPuig P, Penault-Llorca F, Rougier P, Vincenzi B, Santini D, Tonini G, Cappuzzo F, Frattini M, Molinari F, Saletti P, De Dosso S, Martini M, Bardelli A, Siena S, Sartore-Bianchi A, Tabernero J, Macarulla T, Di Fiore F, Gangloff AO, Ciardiello F, Pfeiffer P, Qvortrup C, Hansen TP, Van Cutsem E, Piessevaux H, Lambrechts D, Delorenzi M, Tejpar S (2010) Effects of KRAS, BRAF, NRAS, and PIK3CA mutations on the efficacy of cetuximab plus chemotherapy in chemotherapy-refractory metastatic colorectal cancer: a retrospective consortium analysis. Lancet Oncol 11(8):753-762. https://doi.org/10.1016/S1470-2045(10) 70130-3

7. Cox AD, Fesik SW, Kimmelman AC, Luo J, Der CJ (2014) Drugging the undruggable RAS: Mission possible? Nat Rev Drug Discov 13(11):828-851. https://doi.org/10.1038/ $\operatorname{nrd} 4389$

8. Vaughn CP, Zobell SD, Furtado LV, Baker CL, Samowitz WS (2011) Frequency of KRAS, BRAF, and NRAS mutations in colorectal cancer. Genes Chromosomes Cancer 50(5):307-312. https:// doi.org/10.1002/gcc.20854

9. Timar J, Hegedus B, Raso E (2010) KRAS mutation testing of colorectal cancer for anti-EGFR therapy: dogmas versus evidence. Curr Cancer Drug Targets 10(8):813-823. https://doi.org/10.2174/ 156800910793357989

10. Cohen R, Cervera P, Svrcek M, Pellat A, Dreyer C, de Gramont A, Andre T (2017) BRAF-mutated colorectal cancer: what is the optimal strategy for treatment? Curr Treat Options in Oncol 18(2):9. https://doi.org/10.1007/s11864-017-0453-5

11. Sundar R, Hong DS, Kopetz S, Yap TA (2017) Targeting BRAFmutant colorectal cancer: progress in combination strategies. Cancer Discov 7(6):558-560. https://doi.org/10.1158/2159-8290. CD-17-0087

12. Kopetz S, Desai J, Chan E, Hecht JR, O'Dwyer PJ, Maru D, Morris V, Janku F, Dasari A, Chung W, Issa JP, Gibbs P, James B, Powis G, Nolop KB, Bhattacharya S, Saltz L (2015) Phase II pilot study of Vemurafenib in patients with metastatic BRAF-mutated colorectal cancer. J Clin Oncol 33(34):4032-4038. https://doi.org/10.1200/ JCO.2015.63.2497

13. van Beek E, Pieterman E, Cohen L, Lowik C, Papapoulos S (1999) Farnesyl pyrophosphate synthase is the molecular target of nitrogen-containing bisphosphonates. Biochem Biophys Res Commun 264(1):108-111. https://doi.org/10.1006/bbrc.1999.1499

14. Wang M, Casey PJ (2016) Protein prenylation: unique fats make their mark on biology. Nat Rev Mol Cell Biol 17(2):110-122. https://doi.org/10.1038/nrm.2015.11
15. Forsea AM, Muller C, Riebeling C, Orfanos CE, Geilen CC (2004) Nitrogen-containing bisphosphonates inhibit cell cycle progression in human melanoma cells. Br J Cancer 91(4):803-810. https://doi. org/10.1038/sj.bjc.6602052

16. Garay T, Kenessey I, Molnar E, Juhasz E, Reti A, Laszlo V, Rozsas A, Dobos J, Dome B, Berger W, Klepetko W, Tovari J, Timar J, Hegedus B (2015) Prenylation inhibition-induced cell death in melanoma: reduced sensitivity in BRAF mutant/PTEN wild-type melanoma cells. PLoS One 10(2):e0117021. https://doi.org/10.1371/ journal.pone. 0117021

17. Fragni M, Bonini SA, Bettinsoli P, Bodei S, Generali D, Bottini A, Spano PF, Memo M, Sigala S (2016) The miR-21/PTEN/Akt signaling pathway is involved in the anti-tumoral effects of zoledronic acid in human breast cancer cell lines. Naunyn Schmiedeberg's Arch Pharmacol 389(5):529-538. https://doi.org/10.1007/s00210016-1224-8

18. Ibrahim T, Mercatali L, Sacanna E, Tesei A, Carloni S, Ulivi P, Liverani C, Fabbri F, Zanoni M, Zoli W, Amadori D (2012) Inhibition of breast cancer cell proliferation in repeated and nonrepeated treatment with zoledronic acid. Cancer Cell Int 12(1):48. https://doi.org/10.1186/1475-2867-12-48

19. Mansouri M, Mirzaei SA, Lage H, Mousavi SS, Elahian F (2014) The cell cycle arrest and the anti-invasive effects of nitrogencontaining bisphosphonates are not mediated by DBF4 in breast cancer cells. Biochimie 99:71-76. https://doi.org/10.1016/j.biochi. 2013.11.010

20. Senaratne SG, Pirianov G, Mansi JL, Arnett TR, Colston KW (2000) Bisphosphonates induce apoptosis in human breast cancer cell lines. Br J Cancer 82(8):1459-1468. https://doi.org/10.1054/ bjoc.1999.1131

21. Stachnik A, Yuen T, Iqbal J, Sgobba M, Gupta Y, Lu P, Colaianni G, Ji Y, Zhu LL, Kim SM, Li J, Liu P, Izadmehr S, Sangodkar J, Scherer T, Mujtaba S, Galsky M, Gomez J, Epstein S, Buettner C, Bian Z, Zallone A, Aggarwal AK, Haider S, New MI, Sun L, Narla G, Zaidi M (2014) Repurposing of bisphosphonates for the prevention and therapy of nonsmall cell lung and breast cancer. Proc Natl Acad Sci U S A 111(50):17995-18000. https://doi.org/10.1073/ pnas. 1421422111

22. Di Salvatore M, Orlandi A, Bagala C, Quirino M, Cassano A, Astone A, Barone C (2011) Anti-tumour and anti-angiogenetic effects of zoledronic acid on human non-small-cell lung cancer cell line. Cell Prolif 44(2):139-146. https://doi.org/10.1111/j.13652184.2011.00745.x

23. Tassone P, Tagliaferri P, Viscomi C, Palmieri C, Caraglia M, D'Alessandro A, Galea E, Goel A, Abbruzzese A, Boland CR, Venuta S (2003) Zoledronic acid induces antiproliferative and apoptotic effects in human pancreatic cancer cells in vitro. Br J Cancer 88(12):1971-1978. https://doi.org/10.1038/sj.bjc.6600986

24. Tamura T, Shomori K, Nakabayashi M, Fujii N, Ryoke K, Ito H (2011) Zoledronic acid, a third-generation bisphosphonate, inhibits cellular growth and induces apoptosis in oral carcinoma cell lines. Oncol Rep 25(4):1139-1143. https://doi.org/10.3892/or.2011.1152

25. Michailidou M, Brown HK, Lefley DV, Evans A, Cross SS, Coleman RE, Brown NJ, Holen I (2010) Microvascular endothelial cell responses in vitro and in vivo: modulation by zoledronic acid and paclitaxel? J Vasc Res 47(6):481-493. https://doi.org/10.1159/ 000313876

26. Gao X, Jiang B, Zou S, Zhang T, Qi X, Jin L, Ge X, Tang SC, Hua $\mathrm{D}$, Chen W (2015) Zoledronate can promote apoptosis and inhibit the proliferation of colorectal cancer cells. Tumour Biology : the Journal of the International Society for Oncodevelopmental Biology and Medicine 36(7):5315-5322. https://doi.org/10.1007/ s13277-015-3192-x

27. Sewing L, Steinberg F, Schmidt H, Göke R (2008) The bisphosphonate zoledronic acid inhibits the growth of HCT-116 colon 
carcinoma cells and induces tumor cell apoptosis. Apoptosis 13(6): 782-789. https://doi.org/10.1007/s10495-008-0211-z

28. Kuroda J, Kimura S, Segawa H, Sato K, Matsumoto S, Nogawa M, Yuasa T, Kobayashi Y, Yoshikawa T, Ottmann OG, Maekawa T (2004) p53-independent anti-tumor effects of the nitrogencontaining bisphosphonate zoledronic acid. Cancer Sci 95(2): 186-192. https://doi.org/10.1111/j.1349-7006.2004.tb03202.x

29. Kato J, Futamura M, Kanematsu M, Gaowa S, Mori R, Tanahashi T, Matsuhashi N, Yoshida K (2016) Combination therapy with zoledronic acid and cetuximab effectively suppresses growth of colorectal cancer cells regardless of KRAS status. Int J Cancer 138(6): 1516-1527. https://doi.org/10.1002/ijc.29881

30. Bonovas S, Nikolopoulos G, Bagos P (2013) Bisphosphonate use and risk of colorectal cancer: a systematic review and meta-analysis. Br J Clin Pharmacol 76(3):329-337. https://doi.org/10.1111/ bcp. 12135

31. Rennert G, Pinchev M, Rennert HS, Gruber SB (2011) Use of bisphosphonates and reduced risk of colorectal Cancer. J Clin Oncol 29(9):1146-1150. https://doi.org/10.1200/JCO.2010.33.7485

32. Thosani N, Thosani SN, Kumar S, Nugent Z, Jimenez C, Singh H, Guha S (2013) Reduced risk of colorectal cancer with use of oral bisphosphonates: a systematic review and meta-analysis. J Clin Oncol 31(5):623-630. https://doi.org/10.1200/JCO.2012.42.9530

33. Yang G, Hu H, Zeng R, Huang J (2013) Oral bisphosphonates and the risk of colorectal cancer: a meta-analysis. J Clin Gastroenterol 47(9):741-748. https://doi.org/10.1097/MCG.0b013e31829e446b

34. Morgan GJ, Davies FE, Gregory WM, Cocks K, Bell SE, Szubert AJ, Navarro-Coy N, Drayson MT, Owen RG, Feyler S, Ashcroft AJ, Ross F, Byrne J, Roddie H, Rudin C, Cook G, Jackson GH, Child JA (2010) First-line treatment with zoledronic acid as compared with clodronic acid in multiple myeloma (MRC myeloma IX): a randomised controlled trial. Lancet 376(9757):1989-1999. https://doi.org/10.1016/S0140-6736(10)62051-X

35. James ND, Sydes MR, Clarke NW, Mason MD, Dearnaley DP, Spears MR, Ritchie AWS, Parker CC, Russell JM, Attard G, de Bono J, Cross W, Jones RJ, Thalmann G, Amos C, Matheson D, Millman R, Alzouebi M, Beesley S, Birtle AJ, Brock S, Cathomas R, Chakraborti P, Chowdhury S, Cook A, Elliott T, Gale J, Gibbs S, Graham JD, Hetherington J, Hughes R, Laing R, McKinna F, McLaren DB, O'Sullivan JM, Parikh O, Peedell C, Protheroe A, Robinson AJ, Srihari N, Srinivasan R, Staffurth J, Sundar S, Tolan S, Tsang D, Wagstaff J, Parmar MKB (2016) Addition of docetaxel, zoledronic acid, or both to first-line long-term hormone therapy in prostate cancer (STAMPEDE): survival results from an adaptive, multiarm, multistage, platform randomised controlled trial. Lancet 387(10024):1163-1177. https://doi.org/10.1016/S0140-6736(15)01037-5

36. Coleman R, Cameron D, Dodwell D, Bell R, Wilson C, Rathbone E, Keane M, Gil M, Burkinshaw R, Grieve R, Barrett-Lee P, Ritchie D, Liversedge V, Hinsley S, Marshall H (2014) Adjuvant zoledronic acid in patients with early breast cancer: final efficacy analysis of the AZURE (BIG 01/04) randomised open-label phase 3 trial. Lancet Oncol 15(9):997-1006. https://doi.org/10.1016/S14702045(14)70302-X

37. Rakel A, Boucher A, Ste-Marie LG (2011) Role of zoledronic acid in the prevention and treatment of osteoporosis. Clin Interv Aging 6:89-99. https://doi.org/10.2147/CIA.S7282

38. Weiss HM, Pfaar U, Schweitzer A, Wiegand H, Skerjanec A, Schran H (2008) Biodistribution and plasma protein binding of zoledronic acid. Drug Metab Dispos 36(10):2043-2049. https:// doi.org/10.1124/dmd.108.021071

39. Xia Y, Liu YL, Xie Y, Zhu W, Guerra F, Shen S, Yeddula N, Fischer W, Low W, Zhou X, Zhang Y, Oldfield E, Verma IM (2014) A combination therapy for KRAS-driven lung adenocarcinomas using lipophilic bisphosphonates and rapamycin. Sci Transl Med 6(263):263ra161. https://doi.org/10.1126/scitranslmed.3010382

40. Zhang Y, Cao R, Yin F, Hudock MP, Guo RT, Krysiak K, Mukherjee S, Gao YG, Robinson H, Song Y, No JH, Bergan K, Leon A, Cass L, Goddard A, Chang TK, Lin FY, Van Beek E, Papapoulos S, Wang AH, Kubo T, Ochi M, Mukkamala D, Oldfield E (2009) Lipophilic bisphosphonates as dual farnesyl/ geranylgeranyl diphosphate synthase inhibitors: an X-ray and NMR investigation. J Am Chem Soc 131(14):5153-5162. https:// doi.org/10.1021/ja808285e

41. Nath S, Devi GR (2016) Three-dimensional culture systems in cancer research: focus on tumor spheroid model. Pharmacol Ther 163: 94-108. https://doi.org/10.1016/j.pharmthera.2016.03.013

42. Hack S, Worlein B, Hofner G, Pabel J, Wanner KT (2011) Development of imidazole alkanoic acids as mGAT3 selective GABA uptake inhibitors. Eur J Med Chem 46(5):1483-1498. https://doi.org/10.1016/j.ejmech.2011.01.042

43. Zhang Y, Zhu W, Liu YL, Wang H, Wang K, Li K, No JH, Ayong L, Gulati A, Pang R, Freitas-Junior L, Morita CT, Old-Field E (2013) Chemo-immunotherapeutic anti-malarials targeting isoprenoid biosynthesis. ACS Med Chem Lett 4(4):423-427. https://doi.org/10. $1021 / \mathrm{ml} 4000436$

44. Shirasawa S, Furuse M, Yokoyama N, Sasazuki T (1993) Altered growth of human colon cancer cell lines disrupted at activated $\mathrm{Ki}$ ras. Science 260(5104):85-88

45. Mouradov D, Sloggett C, Jorissen RN, Love CG, Li S, Burgess AW, Arango D, Strausberg RL, Buchanan D, Wormald S, O'Connor L, Wilding JL, Bicknell D, Tomlinson IP, Bodmer WF, Mariadason JM, Sieber OM (2014) Colorectal cancer cell lines are representative models of the main molecular subtypes of primary cancer. Cancer Res 74(12):3238-3247. https://doi.org/10.1158/ 0008-5472.CAN-14-0013

46. Klijn C, Durinck S, Stawiski EW, Haverty PM, Jiang Z, Liu H, Degenhardt J, Mayba O, Gnad F, Liu J, Pau G, Reeder J, Cao Y, Mukhyala K, Selvaraj SK, Yu M, Zynda GJ, Brauer MJ, Wu TD, Gentleman RC, Manning G, Yauch RL, Bourgon R, Stokoe D, Modrusan Z, Neve RM, de Sauvage FJ, Settleman J, Seshagiri S, Zhang Z (2015) A comprehensive transcriptional portrait of human cancer cell lines. Nat Biotechnol 33(3):306-312. https://doi.org/10. 1038/nbt.3080

47. Hegedus L, Padanyi R, Molnar J, Paszty K, Varga K, Kenessey I, Sarkozy E, Wolf M, Grusch M, Hegyi Z, Homolya L, Aigner C, Garay T, Hegedus B, Timar J, Kallay E, Enyedi A (2017) Histone Deacetylase inhibitor treatment increases the expression of the plasma membrane $\mathrm{Ca} 2+$ pump PMCA4 $\mathrm{b}$ and inhibits the migration of melanoma cells independent of ERK. Front Oncol 7:95. https://doi. org/10.3389/fonc.2017.00095

48. Ivanov DP, Parker TL, Walker DA, Alexander C, Ashford MB, Gellert PR, Garnett MC (2014) Multiplexing spheroid volume, resazurin and acid phosphatase viability assays for highthroughput screening of tumour spheroids and stem cell neurospheres. PLoS One 9(8):e103817. https://doi.org/10.1371/ journal.pone. 0103817 
49. Kenessey I, Koi K, Horvath O, Cserepes M, Molnar D, Izsak V, Dobos J, Hegedus B, Tovari J, Timar J (2016) KRAS-mutation status dependent effect of zoledronic acid in human non-small cell cancer preclinical models. Oncotarget 7(48):79503-79514. https:// doi.org/10.18632/oncotarget.12806
50. Kelsey I, Manning BD (2013) mTORC1 status dictates tumor response to targeted therapeutics. Sci Signal 6(294):pe31. https://doi. org/10.1126/scisignal.2004632

Publisher's Note Springer Nature remains neutral with regard to jurisdictional claims in published maps and institutional affiliations.

\section{Affiliations}

\section{Marcell Baranyi ${ }^{1}$ - Dominika Rittler ${ }^{1} \cdot$ Eszter Molnár $^{1} \cdot$ Senji Shirasawa ${ }^{2} \cdot$ István Jalsovszky ${ }^{3} \cdot$ Imre Károly Varga $^{3}$. Luca Hegedűs ${ }^{4}$. Afrodíté Németh ${ }^{5} \cdot$ Magdolna Dank $^{5}$ • Clemens Aigner $^{4}$ • József Tóvári ${ }^{6}$ - József Tímár ${ }^{1}$. Balázs Hegedüs ${ }^{1,4}$ - Tamás Garay ${ }^{1,6,7,8}$}

1 2nd Department of Pathology, Semmelweis University, Budapest H1091, Hungary

2 Department of Cell Biology, Faculty of Medicine, Fukuoka University, Fukuoka, Japan

3 Faculty of Science, Institute of Chemistry, Department of Organic Chemistry, Eötvös Loránd University, Budapest H-1117, Hungary

4 Department of Thoracic Surgery, Ruhrlandklinik, University Duisburg-Essen, D-45239 Essen, Germany
5 Oncology Center, Semmelweis University, Budapest H-1091, Hungary

6 Department of Experimental Pharmacology, National Institute of Oncology, Budapest H-1122, Hungary

7 Pázmány Péter Catholic University Faculty of Information Technology and Bionics, Budapest H-1083, Hungary

8 HAS Postdoctoral Fellowship Program Hungarian Academy of Sciences, Budapest H-1051, Hungary 